TESSE D. STEK

\title{
THE IMPORTANCE OF RURAL SANCTUARIES IN STRUCTURING NON-URBAN SOCIETY IN ANCIENT SAMNIUM: APPROACHES FROM ARCHITECTURE AND LANDSCAPE
}

\begin{abstract}
Summary. This brief article addresses the potential of the study of rural sanctuaries for understanding the performance and general structure of non-urban society in ancient Samnium. Samnium, a mountainous area in central-southern Italy, is known for its non-urbanized settlement organization in the Classical and Hellenistic periods. This article discusses different methodologies to assess the local and regional significance of rural cult sites in this particular societal structure. In reply to a recent article in this journal, it is argued that strong local variability of rural cult sites cannot be ascertained on the basis of the disparate available architectural evidence. On the other hand, it is shown that a landscape archaeological approach, i.e. applying intensive field surveys around Samnite sanctuaries, adds significantly to our understanding of the social function of these cult sites. The surveys (2004present) document a clear nucleation of rural settlement around cult sites, probably reflecting farm-village communities, and demonstrating the strong local embeddedness of the rural cult sites. The order of magnitude of the rural communities living around the sanctuaries is broadly comparable, which gives us a tangible sense of the character and general structure of Samnite nonurban society.
\end{abstract}

\section{INTRODUCTION}

Rural cult places were of central importance in the non-urbanized areas of ancient Samnium, in central-southern Italy. Their precise function in the socio-political organization of these areas, however, and what they meant to different ancient audiences remain important research questions. It is beyond doubt that the major sanctuary site at Pietrabbondante played a key role in the formation and maintenance of a supra-local Samnite socio-political and military organization with ethnic connotations, as monumental inscriptions explicitly attest (Vetter 1953, 149). Beyond this exceptional site, understanding the role of the relatively small sanctuaries that lie scattered over the entire Samnite landscape becomes crucial for assessing the character and 
extent of the overall socio-political organizational structure in the area. In the absence of inscriptions such as those recovered at Pietrabbondante, different datasets and methodologies are needed to interpret the function of these small- and medium- sized sanctuaries within the socio-political and cultural landscape.

Recently in this journal (2014), Rafael Scopacasa has argued that a certain category of minor Samnite sanctuaries exhibits striking local variability, and he links this to the conscious construction of discrete local identities, as opposed to the view that such sanctuaries were merely 'building blocks of the Samnite ethnos' (p. 69). Scopacasa bases his argument mainly on the architectural size and decoration of some of these sanctuaries, notably those at Cupa (Gildone) and Petacciato, but he also draws comparisons to sanctuaries such as those at Colle Rimontato (S. Giovanni in Galdo) and Colle Sparanise.

One cannot but agree with Scopacasa that it is important to study the role of minor sanctuaries in Samnite non-urban society. If relatively small sanctuaries are indeed marked by a very high degree of intentional local differentiation, this might offer potentially valuable insight into the processes at work behind the construction of these sanctuaries, and thus about the overall structure of Samnite society. Scopacasa strongly emphasizes local distinctiveness and localized feelings of 'community membership and belonging' (p. 77), but his conclusions, in my view, are shaped by an artificial categorization of sanctuaries and a selective use of the archaeological material available from these cult sites. We, moreover, have another powerful methodology and dataset at our disposal that can shed unusually bright light on the communities involved in the construction and functioning of these cult sites: landscape archaeology. Field surveys around rural cult sites are, I would argue, ideally suited to answer questions regarding the functioning of small rural sanctuaries, because they can reveal the presence, character and extent of local communities living around such cult places. It can therefore also inform the discussion of the character and variability of the rural cult sites themselves.

In this note, I would like briefly to demonstrate the potential of this specific spatial methodology for understanding Samnite sanctuaries within local society, and its bearing on the overall discussion, by examining previous work and presenting some of the latest findings from the field. Before doing so, however, a brief discussion of the character of Samnite sanctuaries and potential hierarchies among them is in order.

\section{HIERARCHIES OF CULT SITES?}

What constitutes a small Samnite sanctuary, and how does it differ from large-scale sanctuaries such as Pietrabbondante? Generally, scholars distinguish sites such as the impressive, monumental cult complexes at Pietrabbondante and Campochiaro from smaller rural sanctuaries such as Colle Rimontato, Cupa, Pietracupa and Colle Sparanise. Although many classifications of sanctuaries have long been obfuscated by the erroneous and pseudo-historical touto-pagusvicus system, ${ }^{1}$ the basic distinction is quite clear-cut in the existing literature: a sanctuary is usually classified more or less according to the relative energy invested in a cult site in terms of monumentality, decoration, gifts and sacrifices. ${ }^{2}$ Although I am personally wary of strict categorizations and hierarchies and prefer first to consider each cult site in its own right, it is clear

1 See e.g. Letta 1992; Torelli 1988, 72; Lomas 2004, 201-3. Cf. Stek 2009, chs. 4-6 with further references.

2 For hierarchies based on settlement size and catchment areas, cf. Fracchia and Gualtieri 1989; Greco 2000. For a hierarchy of Samnite sanctuaries on the basis of different types of sacrificial animals, see Barker 1989. 
that the cult sites at Pietrabbondante and Campochiaro represent something different from a whole group of sites with less impressive remains. To limit ourselves to the sanctuaries mainly under discussion here, the sites of Colle Sparanise, Cupa and Colle Rimontato in the Pentrian area of the upper Biferno and upper Tappino valleys have universally been regarded as typical examples of small, rural sanctuary sites in the spectrum.

It is therefore surprising (especially in light of the - published - landscape archaeological data, indicating a Samnite village in the area; cf. below) that Scopacasa excludes the small temple of Colle Rimontato from the category of 'village sanctuaries' that he discusses in greater detail, while he includes sites such as Cupa and Colle Sparanise. Even more surprising is the inclusion of the temple at Petacciato, although a wealth of other rural sanctuaries in the inland mountainous area is available but not considered (to name but a few: Frosolone, Pietracupa, Macchiagodena: see Fig. 1). Whereas the sanctuaries mentioned so far pertain to the mountainous, upland area of Samnium traditionally associated with the Samnites Pentri and arguably constitute part of a relatively consistent region in terms of landscape and non-urban socio-political organization, this is decidedly not the case for Petacciato, which is located in the urbanized coastal area near Termoli, and was according to the literary sources inhabited in antiquity by the Frentani, not the Pentri. If it is necessary to categorize sanctuaries at all, such an unorthodox and selective categorization needs to be supported by solid arguments.

Excavations at Colle Rimontato have uncovered a small central cult building (c.7.5 x $8 \mathrm{~m}$ ) surrounded by porticoes measuring roughly $22 \times 22 \mathrm{~m}$ (Di Niro 1980; since 2011, the temple has been under excavation by teams coordinated by the author). Stucco and an opus signinum floor were present. It nonetheless seems unwise to contrast the relatively wellpreserved Colle Rimontato site directly with what very little we know about the Cupa sanctuary: at Cupa, even the location of the sanctuary was unknown until 2004, when our team located it during the field surveys. Yet, even though the sanctuary at Cupa was extremely poorly documented - by a local doctor in the 1930s - elaborate architecture was found even there during the demolition of the remains. Large limestone slabs indicate that the dimensions of the central cult building were 7.83 x 7.85 m (D’Amico 1954, 4). Additional remains, including limestone column bases, were found further afield, about 2 to $4 \mathrm{~m}$ away from the central cult building. In 2005, our team documented a limestone column base at the site, the dimensions of which were very similar to those found in the sanctuary at Colle Rimontato. Stucco and an opus signinum floor were also present at Cupa. On the basis of the descriptions made by the doctor, it is very probable that the cult place had dimensions and perhaps also a general appearance similar to the Colle Rimontato temple (cf. Di Niro 1980 and Di Niro and Petrone 1993, comparing the sanctuary directly to Colle Rimontato). The same is true of the Colle Sparanise sanctuary. No entire temple building has been excavated here, but the 'jumble of limestone blocks and tile' and 'substantial wall of limestone rubble' found are telling (Barker 1995, 87). The soundings taken and pits made by Barker's team led them, rightly, to conclude that the sanctuary was comparable to the Colle Rimontato temple (Barker 1995, 192).

New evidence also points rather to striking similarities than differences of typology or scale. To limit ourselves just to the research area under discussion, we have recently identified a new Samnite cult place at Gildone, S. Andrea. The remains consist of a platform of large limestone blocks, its sides measuring approximately 15-20 m (further research is planned for our next field campaign); and, again, on top of the platform, a limestone column element of dimensions comparable to those found at Cupa and Colle Rimontato. 


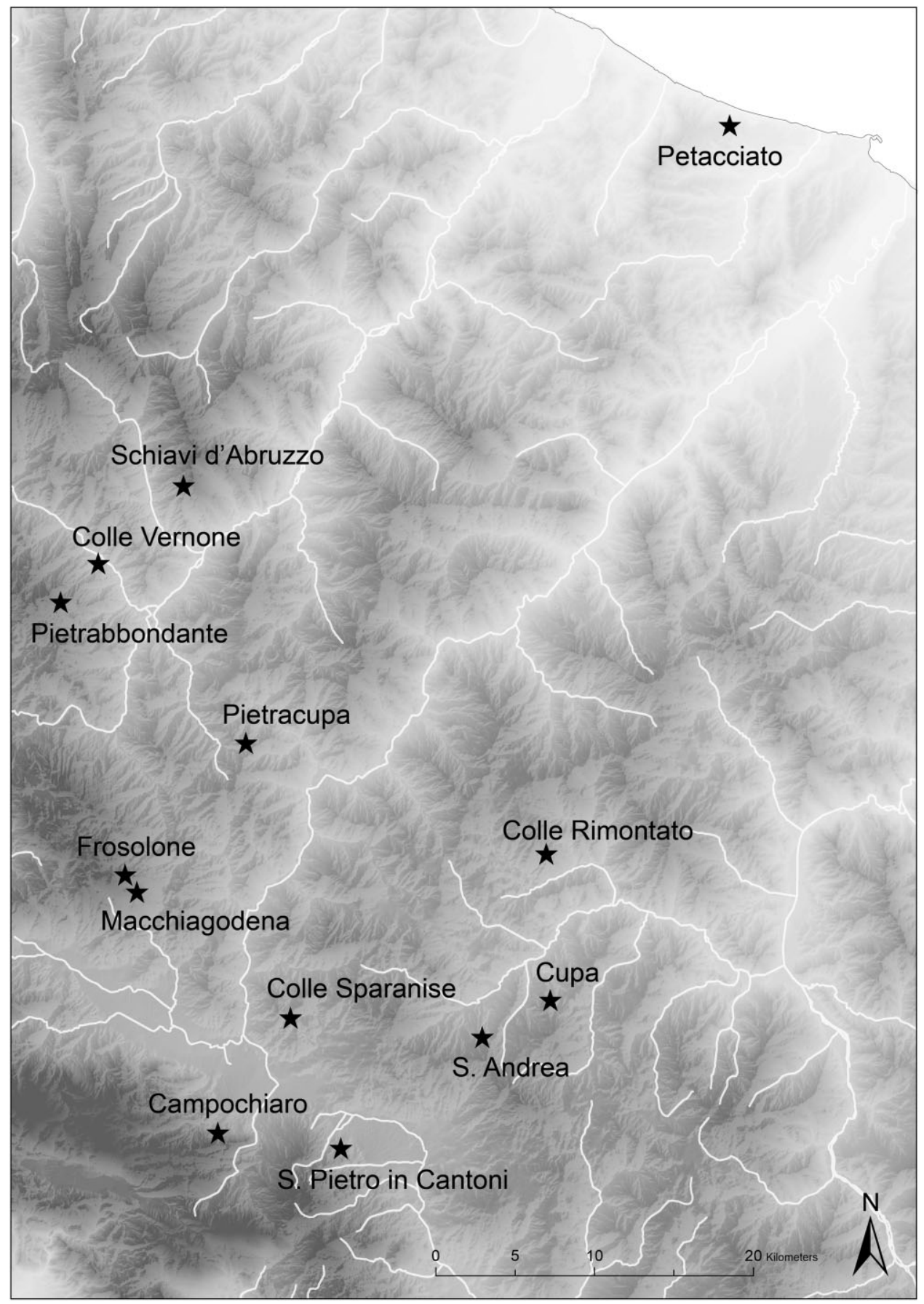

Figure 1

Overview map showing the distribution of the cult places under discussion (map created by R. Kalkers). 
Certainly, we must avoid imposing strict categories or reducing the evidence to uniform types, and we must also resist automatically resorting to one well-known sanctuary type to explain others. ${ }^{3}$ Yet, despite these reservations, I believe most of the cult sites considered here are surprisingly coherent in their overall size and appearance. This overall compatibility, of course, should not be attributed simplistically to exclusive, grand expressions of ethnic affinity (indeed, no scholar would do that in the present state of knowledge), but this pattern arguably does give an idea of the overall structure of society in the region.

If we are looking to establish a wholly different category of cult sites to that at Colle Rimontato, then the examples of Colle Sparanise and Cupa (not to mention the coastal area temple at Petacciato ${ }^{4}$ ) are not well chosen to support a strong contrast between 'stone-built sanctuaries' and 'wood and mud-brick sanctuaries' (esp. pp. 76-80). They all have limestone alibis against being included in the latter category. Also, I fear that the variability Scopacasa notes in his predefined set, rather than being proof of 'a more complex universe of nested identities' (p. 84), is more the result of variations of preservation and documentation of (different phases of) these sites than of a significant difference in the scale and scope of these sanctuaries. Although variability is the norm in Samnite archaeology, I would therefore be cautious in using variations in our available evidence to construct (or de-construct) entire theories, and all the more so if only select elements of sanctuary sites are adduced as evidence of variation, not the complete dataset available (such as the complete terracotta revetment of Cupa). Only a careful synchronic and systematic study, ideally including excavation, but at the least based on first-hand study of all available material from the cult sites, will permit a balanced comparison of their relative importance, difference or similarity. ${ }^{5}$

\section{THE EVIDENCE FROM LANDSCAPE ARCHAEOLOGY}

We do, in fact, have other methods at our disposal for studying the functioning and scope of Samnite rural sanctuaries. As noted above, field surveys can offer valuable insights into the question of the relationship of such sanctuaries to local communities or, alternatively, large-scale polities. Opportunely, this applies a fortiori to the specific debate here, since field research I have been coordinating with colleagues since 2004 as part of the 'Sacred Landscape Project' has targeted these research questions at the sanctuaries of Cupa and Colle Rimontato. Scopacasa does not discuss this evidence: on the one hand, he excludes Colle Rimontato from his category of 'village sanctuaries' and, on the other, he omits our research on the temple of Cupa. It thus seems worthwhile to assess what this distinctive dataset adds to our understanding of these sanctuaries and their audiences. Some of our conclusions on the functioning and purpose of these small sanctuaries have already appeared in print (Stek and Pelgrom 2005; Stek 2009; Pelgrom and Stek 2010), but our most recent fieldwork campaigns have yielded interesting new data,

3 Cf. the discussion of the Latial theatre-temple type: Coarelli 1987; Tagliamonte 2007; Rous 2010; Stek 2014.

4 It is unsurprising that comparison with this sanctuary, an evident geographical and cultural outlier, produces evidence of variability in the dataset, just as comparison with, e.g., a Campanian or Daunian cult site would. It is therefore better to leave it out of this discussion. In any case, monumental remains were also found here before the site was destroyed - the documentation does not allow us to say much more.

5 Regarding genuinely small cult sites, several researchers conducting field surveys, including our teams, have documented small scatters with votive or other potentially 'cultic' material, sometimes directly near large rural settlements (cf., e.g., Sardella 2015). It is possible that some of these sites reflect tiny sites of cultic ritual activity on an entirely different scale to the monumental sites. 
which I will present preliminarily here. I will also take into account evidence from the Biferno Valley Survey (Barker 1995) to support my argument.

I present the archaeological evidence from the surrounding landscape of these three sanctuaries in two stages: first I give a static overview of all contemporary sites recorded in the landscape, then a diachronic analysis of the evolving landscape and community in one case study. In view of the chronological scope of our interest, it seems justified to use black-gloss pottery in the first analysis as a reasonable indicator of sites that may have been contemporary with the cult sites. ${ }^{6}$

Figure 2 below shows all sites in the area of the sanctuaries of Colle Rimontato (A) and Cupa (B) that have produced black-gloss pottery, together with an outline of the research areas.

Figure 3 shows all sites with black-gloss pottery identified by the Biferno Valley Survey in the surroundings of the Colle Sparanise sanctuary.

First of all, a clear concentration of Hellenistic sites may be distinguished in the surroundings of the rural cult sites. Cult sites are located in areas with generally higher site densities, but are not necessarily located within village sites. At Colle Sparanise, significantly, the high density area was first identified as a village, but this interpretation was subsequently corrected, and it was viewed rather as a large, well-spread-out rural settlement or a cluster of separate farms. ${ }^{7}$ At Colle Rimontato, the village was discovered at a distance of $c .500 \mathrm{~m}$ from the cult place, and a related necropolis and scattered sites were also documented in the wider rural area. The site of Cupa and its satellites seem to be related to the nearby hillfort site at Montagna di Gildone, where a large proto-historic and Samnite site has been found $(\mathrm{H})$, and to an important ancient route cutting through the area. The general pattern emerging from the research areas around the sanctuaries of Colle Rimontato (A) and Cupa (B) is now reinforced by intensive off-site surveys of areas further away from the cult sites (C, D, E, F, G), which statistically indicate a much lower site density. Clusters consisting of settlements and cult sites thus seem to be the rule in all three case studies. The image of Samnite cult places as the proverbially isolated 'cathedrals in the desert', on which premise most large-scale interpretations of Samnite sanctuaries have essentially been based, can therefore be dismissed. As I have previously argued, the field survey evidence does not support previous theories that the cult sites marked the territory of a larger, 'ethnic' polity (e.g. D'Ercole 2000). In fact, the whole notion of explaining rural cult sites in light of large-scale political and economic structures (especially transhumance: cf., e.g., Van Wonterghem 1999) may have arisen from the perceived isolation of these cult sites in the landscape: it has become clear now that this isolation was merely an illusion caused by a lack of research. ${ }^{8}$

This conclusion is supported by the detailed diachronic development documented for Colle Rimontato. The initial foundation of the cult site seems to be linked to a pre-existing Iron Age/Archaic village nearby; the cult site would thus pre-date the further 'rural infill' of the entire landscape with small farm sites in the second century $\mathrm{BC}$, which probably reflects a population

6 Field surveys and excavations established that the cult site at Colle Rimontato began to be used in the late fourth century BC (Stek 2009); peak activity at the sanctuary of Cupa also falls in the Hellenistic period (Stek and Pelgrom 2005). The Colle Sparanise sanctuary (C36 in Barker's catalogue) likewise dates to the Hellenistic (and Roman) period.

$7 \quad$ Lloyd 1991, 182; Barker 1995, 49-50.

8 See Stek 2009, ch. 5, 'Landscapes of the Sacred: Contextualising the Samnite Sanctuary of S. Giovanni in Galdo, Colle Rimontato (CB)'. 


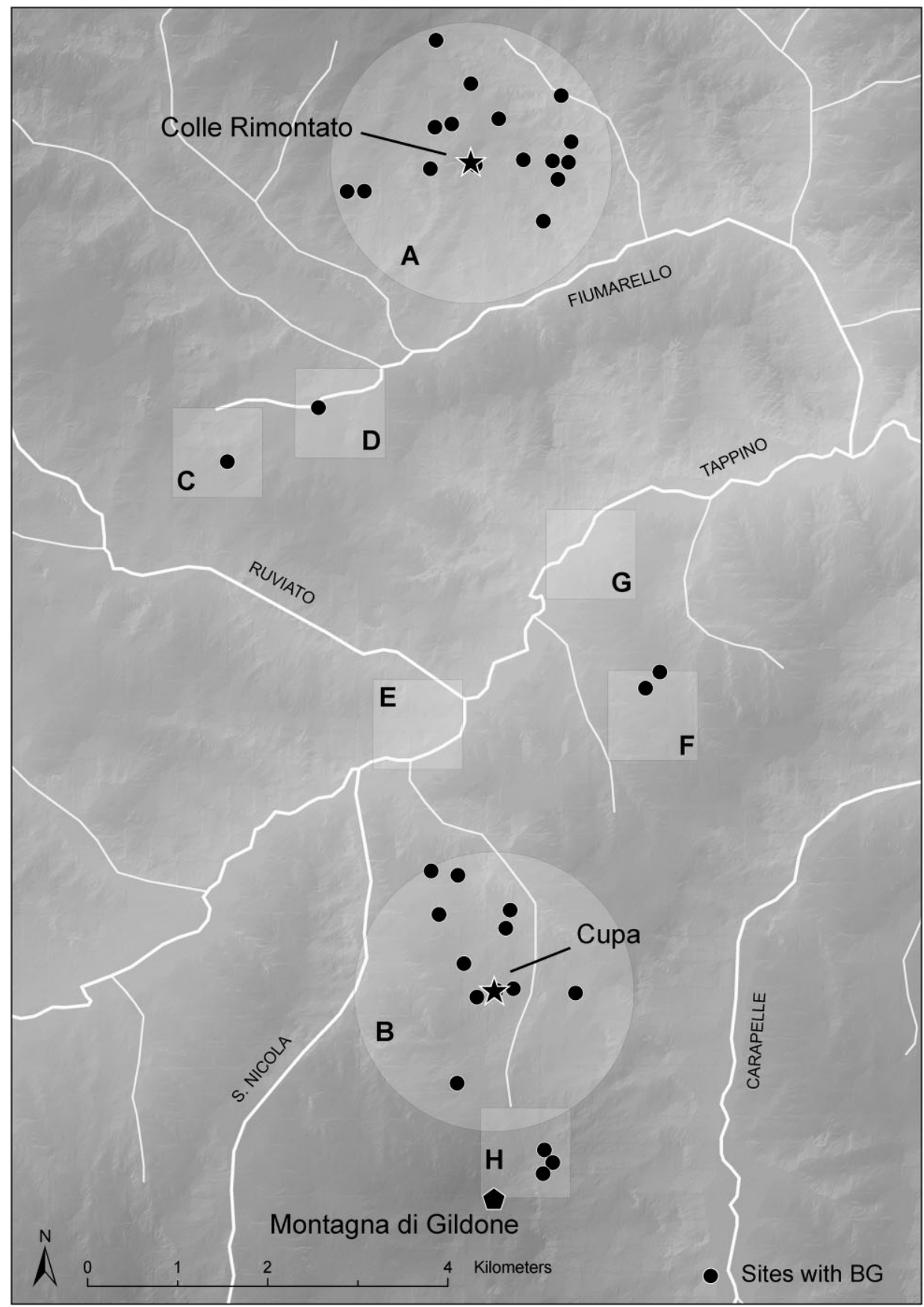

Figure 2

The sanctuaries of Colle Rimontato and Cupa and surrounding sites of the Hellenistic period (map created by R. Kalkers). 


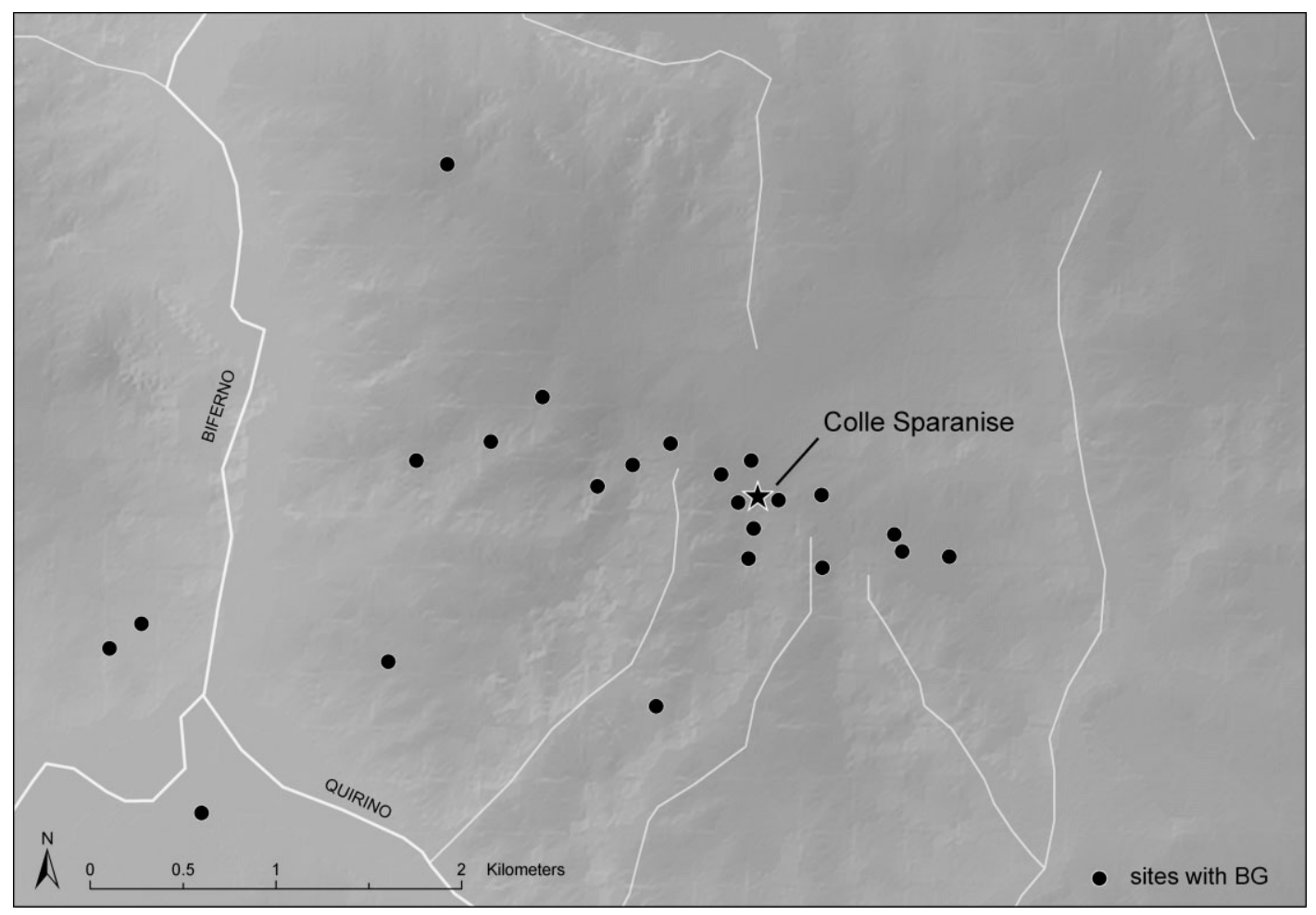

Figure 3

The sanctuary of Colle Sparanise with surrounding sites of the Hellenistic period (map created by R. Kalkers after Barker 1995).

increase and new agricultural strategies. The monumentalization of the site in the late second century BC may be connected to these latter developments. ${ }^{9}$ Local rural communities thus played a key role in the location and functioning of these cult sites. The precise extent and character of the clustering of settlements and cult sites in all research areas remain the subject of our ongoing research, but our preliminary analyses indicate that the clustering patterns seem to be of a similar order of magnitude.

Combined with the generic evidence for the chronology and size of the cult sites, field survey evidence gives us a picture of a structurally rather homogeneous configuration of rural cult sites and settlements, which in turn gives us broad parameters to assess the scale and scope of these sanctuaries. A landscape approach thus not only helps us understand the role and purpose of cult sites in non-urban socio-political organizations, but it also enables us to compare them systematically. According to the present state of research, there is a clear correlation between small Samnite sanctuaries and densely inhabited areas in all cases where intensive investigation has been carried out. Arguably, these dense, local rural communities constituted the building blocks of Samnite society.

9 For the argument, see Stek 2009, ch. 5; for the complete archaeological documentation of all phases, Pelgrom and Stek 2010. 


\section{Acknowledgements}

I would like to thank the comuni of Jelsi, Gildone, Toro, Campodipietra and S. Giovanni in Galdo for their warm hospitality and support, and the many colleagues and team members who over the last ten years contributed in various ways to the fieldwork in Molise, especially Jeremia Pelgrom, Rogier Kalkers and Jitte Waagen. I would like to thank in particular Michele Fratino for his energetic and invaluable support in Jelsi. The presented research has been made possible by various grants from the Netherlands Organization for Scientific Research (NWO).

Faculty of Archaeology

Leiden University

Reuvensplaats 3-4

2311 BE Leiden

THE NETHERLANDS

E-mail: t.d.stek@arch.leidenuniv.nl

\section{REFERENCES}

BARKER, G. 1989: Animals, ritual and power in ancient Samnium. In MENIEL, P. (ed.), Animal et pratiques religieuses. Les manifestations matérielles. Actes du colloque international de Compiègne, 11-13 novembre 1988 (Paris), 111-17.

BARKER, G. (ed.) 1995: A Mediterranean Valley. Landscape Archaeology and Annales History in the Biferno Valley (London, New York).

COARELLI, F. 1987: I santuari del Lazio in età repubblicana (Rome).

D'AMICO, v. 1954: Il tempietto italico di Romulea e il valore della sua scoperta. Samnium 27, 193-208.

D'ERCOLE, V. 2000: I 'paesaggi di potere' dell'Abruzzo protostorico. In CAMASSA, G., DE GUIO, A. and VERONESE, F. (eds.), Paesaggi di potere (Rome), 121-52.

DI NIRO, A. 1980: Il santuario di S. Giovanni in Galdo. In Sannio. Pentri e Frentani dal VI al I sec. a.C. Isernia, Catalogo della mostra (Rome), 269-81.

DI NIRO, A. and PETRONE, P.P. 1993: Insediamenti di epoca sannitica nel territorio circostante la valle del torrente Tappino (Campobasso, Molise). Papers of the British School at Rome 61, 7-49.

FRACCHIA, H.M. and GUALTIERI, M. 1989: The social context of cult practices in pre-Roman Lucania. American Journal of Archaeology 93, 217-32.

GRECO, E. 2000: Santuari indigeni e formazione del territorio in Lucania. In VERGER, S. (ed.), Rites et espaces en pays celte et méditerranéen (Rome), 223-9.

LETTA, C. 1992: I santuari rurali nell'Italia centro-appenninica: valori religiosi e funzione aggregativa. Mélanges de l'École française de Rome, Antiquité 104, 109-24.

LLOYD, J. 1991: Farming the highlands. Samnium and Arcadia in the Hellenistic and early Roman Imperial periods. In BARKER, G. and LlOYD, J. (eds.), Roman Landscapes: Archaeological Survey in the Mediterranean Region (London), 180-93.

LOMAS, K. 2004: Italy during the Roman republic, 338-31 B.C. In FLOwER, H.I. (ed.), The Cambridge Companion to the Roman Republic (Cambridge), 199-224.

PELGROM, J. and STEK, T.D. 2010: A landscape archaeological perspective on the functioning of a rural cult place in Samnium: field surveys around the sanctuary of S. Giovanni in Galdo (Molise). Journal of Ancient Topography 20, 41-102.

ROUS, B.D. 2010: Triumphs of Compromise (Ph.D. Thesis, University of Amsterdam).

SARDELLA, B. 2015: Su alcuni luoghi di culto rurali nel Sannio pentro e frentano: rapporti con territorio, viabilità e insediamento. In STEK, T.D. and BURGERS, G.J. (eds.), The Impact of Rome on Cult Places and Religious Practices in Ancient Italy (London), 261-92.

SCOPACASA, R. 2014: Building communities in ancient Samnium: cult, ethnicity and nested identities. Oxford Journal of Archaeology 33(1), 69-87.

STEK, T.D. 2009: Cult Places and Cultural Change in Republican Italy. A Contextual Approach to Religious Aspects of Rural Society after the Roman Conquest (Amsterdam). 
STEK, T.D. 2014: Monumental architecture of non-urban cult places in Roman Italy. In QUENEMOEN, C. and ULRICH, R. (eds.), The Blackwell Companion to Roman Architecture (Malden, MA), 228-47.

STEK, T.D. and PELGROM, J. 2005: Samnite sanctuaries surveyed. Preliminary report of the sacred landscape project 2004. BABESCH 80, 65-71.

TAGLIAMONTE, G. 2007: Considerazioni sull' architettura santuariale di età tardo-repubblicana tra Campania e Sannio. In QUILICI, L. and QUILICI GIGLI, S. (eds.), Architettura pubblica e privata nell'Italia antica (Rome), 53-68.

TORELLI, M. 1988: Le popolazioni dell'Italia antica: società e forme del potere. In SCHIAVONE, A. (ed.), Storia di Roma. 1: Roma in Italia (Turin), 53-74.

VAN WONTERGHEM, F. 1999: Il culto di Ercole e la pastorizia nell'Italia centrale. In PETROCELLI, E. (ed.), $L a$ civiltà della transumanza (Isernia), 413-28.

VETTER, E. 1953: Handbuch der italischen Dialekte (Heidelberg). 